\title{
Anthrax among heroin users in Europe possibly caused by same Bacillus anthracis strain since 2000
}

R Grunow (GrunowR@rki.de) ${ }^{1}$, S R Klee ${ }^{1}$, W Beyer ${ }^{2}$, M George $^{1}$, D Grunow ${ }^{1}$, A Barduhn ${ }^{1}$, S Klar ${ }^{1}$, D Jacob ${ }^{1}$, M Elschner ${ }^{3}$, P Sandven ${ }^{4}$, A Kjerulf ${ }^{5}$, J S Jensen ${ }^{5}$, W Cai ${ }^{6}$, R Zimmermann ${ }^{6}$, L Schaade ${ }^{1}$

1. Robert Koch Institute, Centre for Biological Threats and Special Pathogens, Berlin, Germany

2. University of Hohenheim, Institute of Environmental and Animal Hygiene, Stuttgart, Germany

3. Friedrich-Loeffler-Institut, Institute of Bacterial Infections and Zoonoses, Jena, Germany

4. Norwegian Institute of Public Health, Department of Bacteriology and Immunology, Oslo, Norway

5. Statens Serum Institut, National Institute for Health Data and Disease Control, Copenhagen, Denmark

6. Robert Koch Institute, Department for Infectious Disease Epidemiology, Berlin, Germany

Citation style for this article:

Grunow R, Klee SR, Beyer W, George M, Grunow D, Barduhn A, Klar S, Jacob D, Elschner M, Sandven P, Kjerulf A, Jensen JS, Cai W, Zimmermann R, Schaade L.

Anthrax among heroin users in Europe possibly caused by same Bacillus anthracis strain since 2000. Euro Surveill. 2013;18(13): pii=20437. Available online: http:// www.eurosurveillance.org/ViewArticle.aspx?Articleld $=20437$

Article submitted on 18 October 2012 / published on 28 March 2013

Injection anthrax was described first in 2000 in a heroin-injecting drug user in Norway. New anthrax cases among heroin consumers were detected in the United Kingdom (52 cases) and Germany (3 cases) in 2009-10. In June 2012, a fatal case occurred in Regensburg, Bavaria. As of December 2012, 13 cases had been reported in this new outbreak from Germany, Denmark, France and the United Kingdom. We analysed isolates from 2009-10 and 2012 as well as from the first injection anthrax case in Norway in 2000 by comparative molecular typing using a high resolution 31 marker multilocus variable-number tandem repeat analysis (MLVA) and a broad single nucleotide polymorphism (SNP) analysis. Our results show that all cases may be traced back to the same outbreak strain. They also indicate the probability of a single source contaminating heroin and that the outbreak could have lasted for at least a decade. However, an additional serological pilot study in two German regions conducted in $\mathbf{2 0 1 1}$ failed to discover additional anthrax cases among 288 heroin users.

\section{Introduction}

Anthrax infections occur world-wide, but are more frequent in countries with subtropical climate for example in southern Europe, the Balkans, south-east Asia, South America and Sub-Saharan Africa. Primary infections predominantly occur in ungulates, whereas human infections are rather rare and usually associated with contact to infected animals or contaminated animal products, such as meat, fur, bone meal, wool or hair $[1,2]$. Human to human transmission is rare.

\section{FIGURE 1}

Published laboratory-confirmed anthrax cases in heroin users 2000 to 2012 as of 31 December 2012 (n=69)

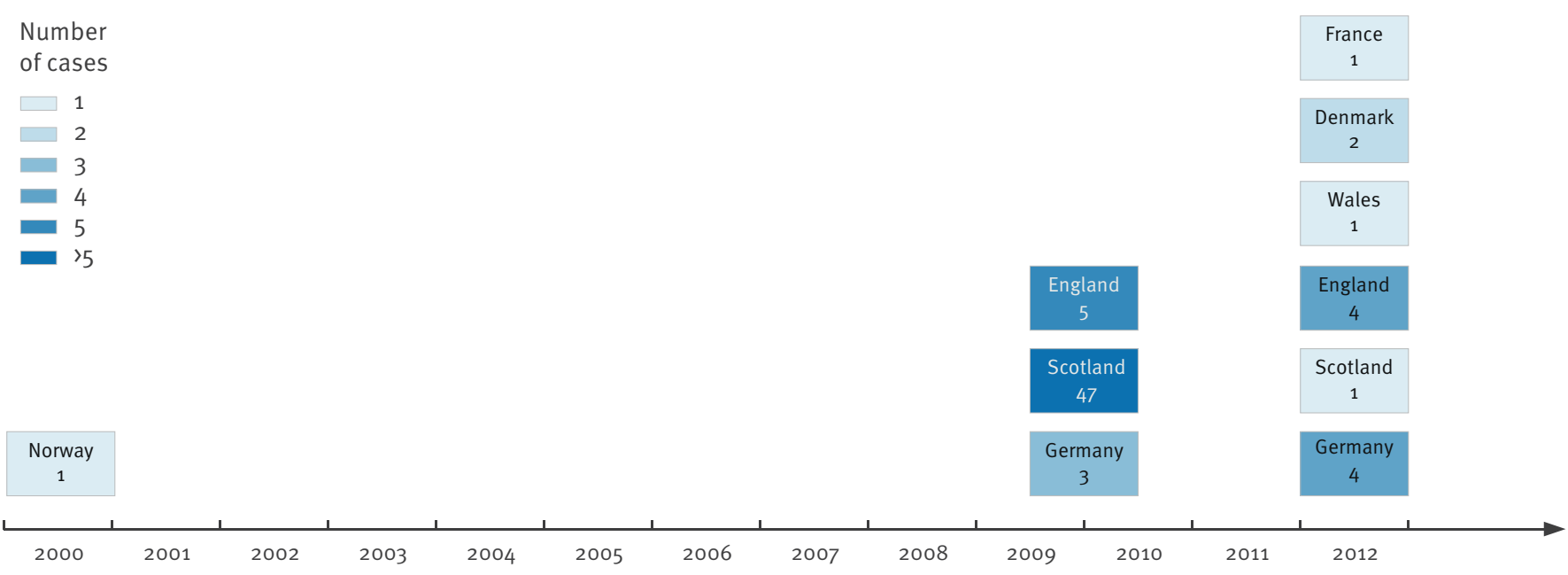


TABLE 1

Isolates from anthrax cases in injecting drug users between 2000 and 2012 used for molecular typing

\begin{tabular}{|l|c|l|}
\hline Designation & $\begin{array}{c}\text { Year of } \\
\text { isolation }\end{array}$ & Source \\
\hline A112a, A112ba & 2009 & $\begin{array}{l}\text { Friedrich-Loeffler-Institute, } \\
\text { Jena, Germany }\end{array}$ \\
\hline A138 & 2010 & $\begin{array}{l}\text { Friedrich-Loeffler-Institute, } \\
\text { Jena, Germany }\end{array}$ \\
\hline A294 & 2012 & $\begin{array}{l}\text { Statens Serum Institute, } \\
\text { Copenhagen, Denmark }\end{array}$ \\
\hline A306 & 2012 & $\begin{array}{l}\text { Statens Serum Institute, } \\
\text { Copenhagen, Denmark }\end{array}$ \\
\hline A303 $3^{b}$ & 2012 & $\begin{array}{l}\text { Charité Berlin, Robert Koch } \\
\text { Institute, Berlin, Germany }\end{array}$ \\
\hline A315/1, A315/2 & 2000 & $\begin{array}{l}\text { Norwegian Institute of } \\
\text { Public Health, Oslo, Norway }\end{array}$ \\
\hline
\end{tabular}

a A112a and A112b refer to different colony morphologies of the same isolate.

b Only DNA from clinical sample, skin swab, available.

Isolates from the same case, below summarised as A315_2000.
Bacillus anthracis is a gram-positive, spore-forming, aerobic rod-like bacterium which grows in chains and is surrounded by a capsule under microaerophilic conditions (cultivation at $5 \% \mathrm{CO}_{2}$ percentage of air) [2]. The bacterium is classified as biological Hazard Group 3 agent [11]. In Germany and at European level, a suspected or laboratory-confirmed anthrax infection according to the case definition is notifiable and has to be reported to the German health authorities who forward the information to the European surveillance system (TESSy) operated by the European Centre for Disease Prevention and Control (ECDC) in Stockholm, Sweden. Particular characteristics of anthrax spores are their extreme resistance against unfavourable environmental influences over a long period of time, enabling them to survive for decades. Spore decontamination requires autoclaving or appropriate chemical disinfectants such as peracetic acid or formaldehyde [12].

The diagnosis of anthrax is mainly based on polymerase chain reaction (PCR) directed against the virulence plasmid markers and isolation of the pathogen from clinical samples [2]. Specific antibody detection can support the diagnoses or discover anthrax cases in epidemiological investigations $[13,14]$.

Early antibiotic therapy [3] is required and schemes for chemoprophylaxis as well as passive and active vaccination are available although vaccines are only approved in some European countries $[4,15]$.

Three outbreaks of injection anthrax in heroin users have been detected so far in Europe (Figure1). The first case was reported from Norway in 2000 [16] and in 2009-10, a total of 119 similar cases occurred in Scotland of which 47 were laboratory-confirmed anthrax cases. Further five cases were reported from England and three from Germany with one case retrospectively detected by serology in a heroin user recovered from a severe disease compatible with injection anthrax $[4,17,18]$. The most recent outbreak started in 2012 and as of December 2012 at least 13 cases occurred in Germany, France, Denmark and United Kingdom [10,19-24], five of whom died. Since all cases of injection anthrax identified involved exclusively active heroin users, contaminated heroin appears to be the most likely source of infection [4].

In our study we were interested to investigate by molecular typing of the isolates whether the first observed case of injection anthrax in 2000 was related to the more recent cases. Moreover, it is not known if the detected cases of injection anthrax over time reflect the real number of infections or if they are the tip of an iceberg. To investigate this question, a retrospective pilot study among German IDUs, including a questionnaire and serology, was initiated and this study is presented here in brief. 
TABLE 2

Code values for the 31 markers used in multilocus variable-number tandem repeat analysis (MLVA)

\begin{tabular}{|c|c|c|c|c|c|c|c|c|}
\hline \multirow[b]{2}{*}{ MLVA-Marker } & \multicolumn{5}{|c|}{ Expected Fragment Lengths (bp) } & \multirow{2}{*}{$\begin{array}{c}\text { Observed } \\
\text { Fragment } \\
\text { Lengths (bp) }\end{array}$} & \multirow{2}{*}{$\begin{array}{c}\text { Code-No. } \\
{[24]}\end{array}$} & \multirow{2}{*}{$\begin{array}{c}\text { reference } \\
\text { Ames } \\
\text { ancestor }\end{array}$} \\
\hline & A112a (2009) & A112b (2009) & A138 (2010) & $\begin{array}{l}\text { A294, A303, } \\
\text { A306 (2012) }\end{array}$ & $\begin{array}{c}\text { A315/1, } \\
\text { A315/2 (2000) }\end{array}$ & & & \\
\hline Bams 1 & 422 & 422 & 422 & 422 & 422 & $425-429$ & 13 & 2 \\
\hline Bams 3 & 609 & 609 & 609 & 609 & 609 & 616 & 30 & 8 \\
\hline Bams 5 & 307 & 307 & 307 & 307 & 307 & $304-305$ & 5 & 26 \\
\hline Bams 13 & 454 & 454 & 454 & 454 & 454 & 456 & 30 & 13 \\
\hline Bams 15 & 616 & 616 & 616 & 616 & 616 & $616-619$ & 46 & 5 \\
\hline Bams 21 & 676 & 676 & 676 & 676 & 676 & $673-676$ & 9 & 25 \\
\hline Bams 22 & 735 & 735 & 735 & 735 & 735 & $727-731$ & 13 & 16 \\
\hline Bams 23 & 651 & 651 & 651 & 651 & 651 & $644-648$ & 10 & 53 \\
\hline Bams 24 & 595 & 595 & 595 & 595 & 595 & $604-609$ & 9 & 70 \\
\hline Bams 25 & 376 & 376 & 376 & 376 & 376 & $379-380$ & 3 & 17 \\
\hline Bams 28 & 493 & 493 & 493 & 493 & 493 & $500-501$ & 14 & 14 \\
\hline Bams 30 & 862 & 889 & 889 & 889 & 889 & $876 / 902-906$ & $72 / 75$ & 15 \\
\hline Bams 31 & 772 & 772 & 772 & 772 & 772 & 776 & 64 & 8 \\
\hline Bams 34 & 425 & 425 & 425 & 425 & 425 & $431-433$ & 7 & 64 \\
\hline Bams 44 & 417 & 417 & 417 & 417 & 417 & $422-425$ & 8 & 4 \\
\hline Bams 51 & 493 & 493 & 493 & 493 & 493 & 501 & 9 & 4 \\
\hline Bams 53 & 236 & 236 & 236 & 236 & 236 & $234-235$ & 8 & 9 \\
\hline $\mathrm{CG}_{3}$ & 158 & 158 & 158 & 158 & 158 & 157 & 2 & 9 \\
\hline pXO1 & 135 & 135 & 135 & 135 & 135 & 133 & 9 & 9 \\
\hline $\mathrm{pXO}_{2}$ & 137 & 137 & 137 & 139 & 141 & $136 / 138 / 140$ & $7 / 8 / 9$ & 6 \\
\hline vrrA & 314 & 314 & 314 & 314 & 314 & $311-312$ & 4 & 9 \\
\hline vrrB1 & 229 & 229 & 229 & 229 & 229 & 226 & 17 & 9 \\
\hline vrrB2 & 162 & 162 & 162 & 162 & 162 & $159-160$ & 14 & 13 \\
\hline $\mathrm{vrrC}_{1}$ & 616 & 616 & 616 & 616 & 616 & $621-630$ & 57 & 10 \\
\hline $\operatorname{vrrC2}$ & 604 & 604 & 604 & 604 & 604 & $603-605$ & 19 & 57 \\
\hline VNTR 12 & 115 & 115 & 115 & 115 & 115 & 113-114 & 6 & 4 \\
\hline VNTR 16 & 273 & 273 & 273 & 273 & 273 & $266-270$ & 8 & 4 \\
\hline VNTR 17 & 386 & 386 & 386 & 386 & 386 & $386-387$ & 4 & 6 \\
\hline VNTR 19-2 & 99 & 99 & 99 & 99 & 99 & $96-97$ & 5 & 4 \\
\hline VNTR 23 & 197 & 197 & 197 & 197 & 197 & $195-196$ & 4 & 8 \\
\hline VNTR 35 & 109 & 109 & 109 & 109 & 109 & $109-110$ & 3 & 4 \\
\hline
\end{tabular}

A112a and b, A138 Germany (2 different cases)

A294, A306 Denmark (2 different cases)

Азо3 Germany

A315/1, A315/2 Norway (2 isolates from same case)

Code numbers are identical with copy numbers of the repeat sequences, where possible. For the purpose of normalisation the appropriate copy code numbers are added for the Ames Ancestor strain as deduced from the sequence available at GenBank, accession no.: AE017334.2 $\mathrm{Gl}: 50082967$. Expected fragment lengths are taken from the values of alleles provided by Lista et al. in 2006 [27] and deduced from sequences of Bacillus anthracis available at Genbank. Values of alleles not published were artificially added by interpolation using the appropriate repeat lengths. 


\section{FIGURE 2}

Cluster analysis of Bacillus anthracis outbreak isolates from Europe, Asia and southern Africa $(\mathrm{n}=904)$

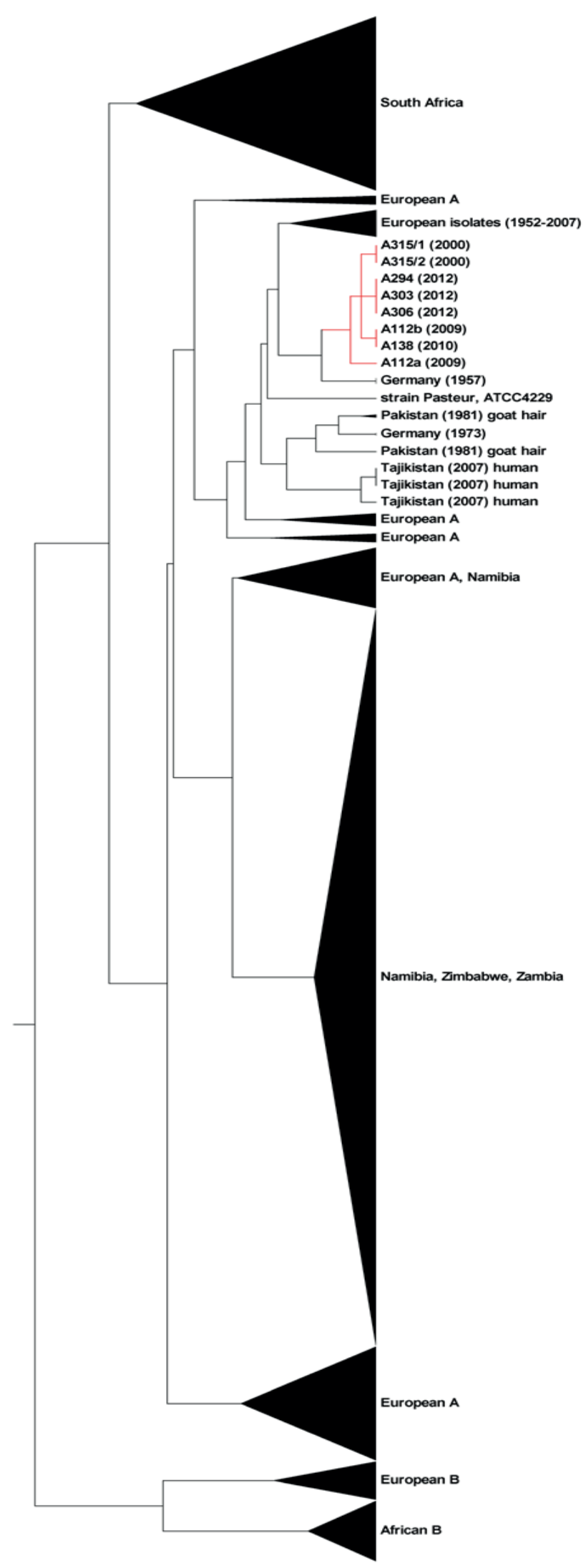

Dendrogram based on multilocus variable-number tandem repeat analysis (MLVA-31) typing of isolates. Diamond shapes indicate the 'heroin anthrax' isolates. For the cluster analysis by unweighted pair group method with arithmetic mean (UPGMA) a categorical coefficient was used.

\section{Methods}

Molecular typing of Bacillus

anthracis outbreak strains

Bacterial isolates found in drug-related clinical anthrax cases are shown in Table 1. Template DNA for PCR was either isolated using the DNeasy Blood \& Tissue Kit (Qiagen, Hilden, Germany) or by boiling of colony material in PBS in a thermoblock at $110^{\circ} \mathrm{C}$ for $20 \mathrm{~min}$.

Multilocus variable-number tandem repeat analysis (MLVA) for analysis of 31 markers was performed with multiplex PCR and capillary electrophoresis as described $[25,26]$. Code numbers in Table 2 reflect the copy numbers of the repeat sequences, where possible. For the purpose of normalisation, the appropriate copy code numbers are added for the Ames Ancestor strain as deduced from the sequence available at GenBank, accession No.: AE017334.2 GI:50082967. Expected fragment lengths are taken from the values of alleles provided by [27] and deduced from sequences of $B$. anthracis available in Genbank. Values of alleles not published were artificially added by interpolation using the appropriate repeat lengths. Data were processed using Bionumerics software package version 5.10 (Applied Maths). For cluster analysis by unweighted pair group method with Arithmetic Mean (UPGMA) a categorical coefficient was used.

Single nucleotide polymorphism (SNP) analyses for the 13 canonical SNPs (canSNPs) described by Van Ert et al. in 2007 [28] as well as for the two SNPs, SNP1173928 and SNP1053700, which were identified to be specific for the outbreak strains from 200910 [29] were performed using conventional PCR and sequencing of the appropriate regions with standard methods. Further SNPs (A.Br.011, SNP5013862, SNP1967560, SNP1118831, SNP1530761, SNP3287006 and SNP3836105) with increasing specificity for the 'heroin isolates' [29] were additionally included.

The methods and results for the pilot study on retrospective case finding are presented under a separate heading.

\section{Results}

\section{Multilocus variable-number tandem repeat analysis (MLVA)}

The results from the MLVA showed that 'heroin anthrax' isolates including strain A315_2000 belong to the European A cluster. Interestingly, two slightly different colony morphologies were observed for isolate A112, and further subcultivation resulted in subclones A112a and A112b. These subclones differed by three repeat units in marker Bams30. All other MLVA markers were identical in all isolates tested, except for the marker for the virulence plasmid $\mathrm{pXO}_{2}$ (Table 3). The oldest isolates from the year 2000 (A315/1 and $A 315 / 2)$ from the same patient in Norway, held nine AT repeats; 


\section{FIGURE 3}

Minimum spanning tree isolates of Bacillus anthracis typed by 31-marker multilocus variable-number tandem repeat analysis (MLVA) (n=904)

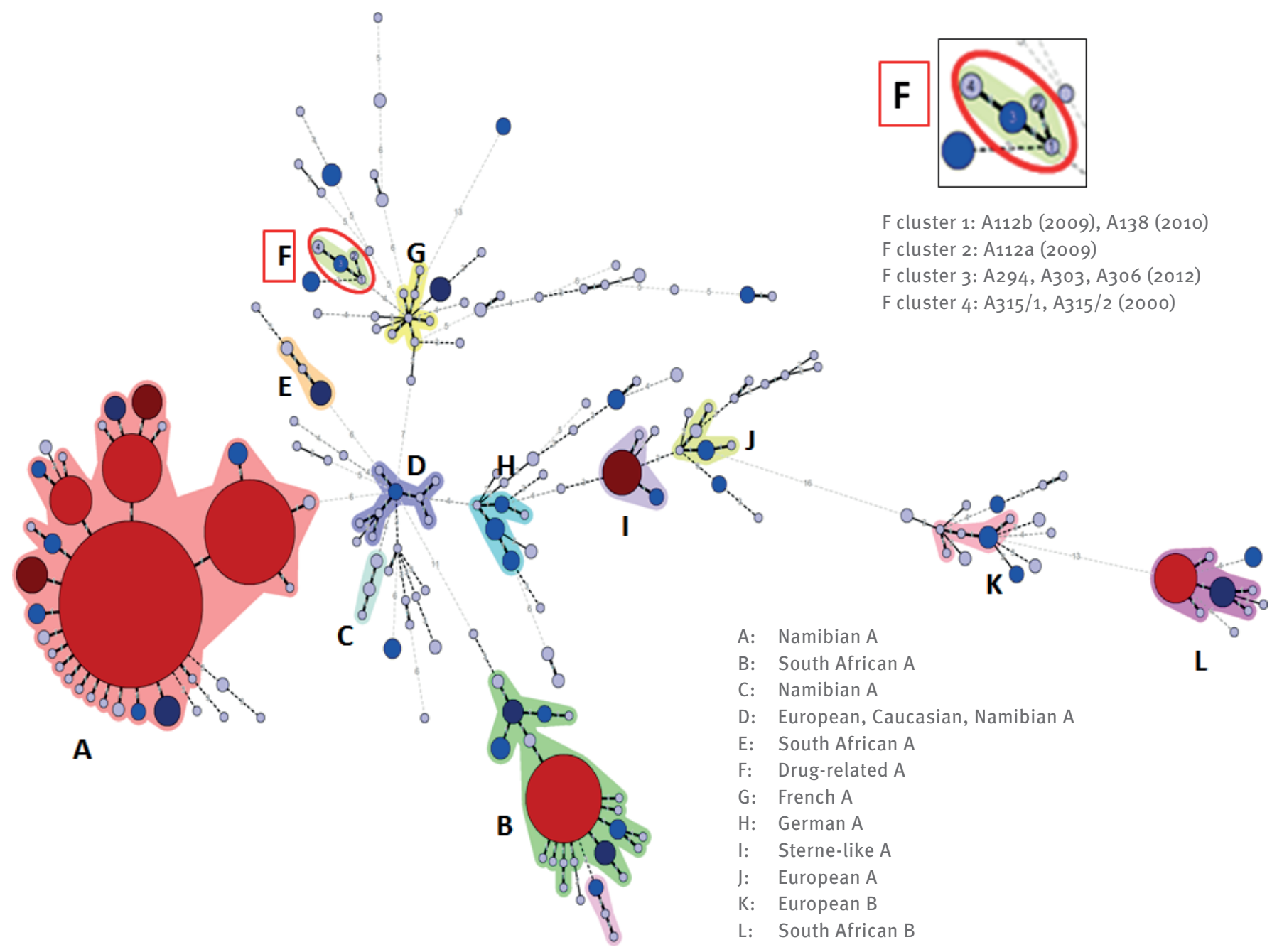

Clustering of multilocus variable-number tandem repeat analysis (MLVA) profiles was done using a categorical coefficient. MLVA-Genotypes (GT) are displayed as circles. The size of each circle symbolises the number of isolates of this particular GT. GTs differing in only one marker are combined in a complex seen as a coloured halo if at least three GTs fulfil this criterion. Distances between circles do not reflect the correct phylogenetic distances. The letters A and B in the legend reflect the main MLVA clusters as defined by Keim et al in 200o [26]. The F-complex comprises the eight drug-related isolates.

the outbreak isolates from 2009-10 had seven repeats and the latest isolates from 2012 carried eight repeats. A comparison of the heroin-related strains with a collection of 904 isolates from Europe, Asia and southern Africa is shown in Figure 2.

The minimum spanning tree of the investigated isolates is shown in figure 3. The F-complex comprises the eight drug-related isolates arranged according to the number of different markers (one each between the clusters). The sequence of clusters is not expected to reflect the true ancestry of the isolates because of the high mutability and possible homoplasy in both markers Bams30 and pXO2. Interestingly, both the F- and the G-complex are clearly differentiated from the rest of the European and worldwide isolates by seven variable-number tandem repeat (VNTR)-markers, though still differing from each other by another four VNTR-markers. Whether or not this indicates an ancient common group of ancestors could only be answered by including the VNTR-data of strains from the east Turkish region, which are considered near relatives of the heroin-based isolates by the SNP-analysis. 
Single nucleotide polymorphism (SNP) for clustering and strain identification in isolates from anthrax cases in injecting drug users between 2000 and $2012(n=8)$

\begin{tabular}{|c|c|c|c|c|}
\hline Method & $\begin{array}{l}\text { Strains } 2009-2012 \\
\text { in this study }\end{array}$ & $\begin{array}{l}\text { Strain A315_2000 } \\
\text { in this study }\end{array}$ & $\begin{array}{l}\text { Other outbreak strains with } \\
\text { reference to Price et al.[28] [30] }\end{array}$ & Peculiarities \\
\hline 13 SNPs PCR [28] & $\begin{array}{l}\text { Present indicating } \\
\text { as a member of } \\
\text { A.Br.008/009 group }\end{array}$ & $\begin{array}{l}\text { Present indicating } \\
\text { as a member of } \\
\text { A.Br.008/009 } \\
\text { group }\end{array}$ & $\begin{array}{c}\text { A.Br.008/009 group; } \\
36 \text { isolates including outbreak } \\
\text { type strain Ba } 4599 \text { were typed } \\
\text { to this group }\end{array}$ & $\begin{array}{l}\text { 384/1,033 worldwide isolates } \\
\text { were typed to A.Br.0o8/oo9 } \\
\text { group representing a subset of } \\
\text { Trans-Eurasian group [28] }\end{array}$ \\
\hline A.Br.011 PCR [29] & $\begin{array}{l}\text { Present indicating as a } \\
\text { member of the } \\
\text { A.Br.008/011 lineage }\end{array}$ & $\begin{array}{c}\text { Present indicating as a } \\
\text { member of the } \\
\text { A.Br.oo8/011 } \\
\text { lineage }\end{array}$ & $\begin{array}{l}\text { A.Br.008/011 } \\
\text { outbreak type strain Ba4599 }\end{array}$ & $\begin{array}{l}120 \text { other isolates from } \\
\text { different countries, including } \\
\text { six Turkish isolates [29] }\end{array}$ \\
\hline $\begin{array}{l}3 \text { additional SNPs [29] } \\
-5013862 \\
-1967560 \\
-1118831\end{array}$ & Present & Present & $\begin{array}{l}\text { Present outbreak type strain } \\
\text { Ba4599 }\end{array}$ & $\begin{array}{l}\text { Present in Turkish isolates } \\
\text { A0149 and Ao264 but not in } \\
\text { four other Turkish strains [29] }\end{array}$ \\
\hline $\begin{array}{l}3 \text { additional SNPs [29] } \\
-1530761 \\
-3287006 \\
-3836105 \\
\end{array}$ & Present & Present & $\begin{array}{l}\text { Present outbreak type strain } \\
\text { Ba4599 }\end{array}$ & $\begin{array}{l}\text { Present in Turkish isolates } \\
\text { A0149 and Ao264 but not in } \\
\text { four other Turkish strains [29] }\end{array}$ \\
\hline $\begin{array}{l}2 \text { additional SNPs [29] } \\
-10553700-1173928\end{array}$ & Present & Present & $\begin{array}{c}\text { Present } \\
\text { in } 36 \text { isolates including } \\
\text { outbreak type strain Ba4599 }\end{array}$ & $\begin{array}{l}\text { Not in A0149 and Ao264 and } \\
\text { four other Turkish strains [29] }\end{array}$ \\
\hline
\end{tabular}

Single nucleotide polymorphism (SNP) analyses As already shown for the isolates from the outbreak of 2009-10, canSNP genotyping (13 SNPs) of all isolates tested in this study revealed that they belong to the A.Br.008/009 group, the so-called Trans-Eurasian group [28]. The presence of seven further SNPs (A.Br.011, SNP5013862, SNP1967560, SNP1118831, SNP1530761, SNP3287006 and SNP3836105) with increasing specificity, that were used to identify the closest relatives of the outbreak isolates, were also confirmed (Table 3 ). In addition, all isolates shared the two SNPs (SNP1173928 and SNP1053700) that were shown to be distinctive for the anthrax cases in heroin users. The presence of these two SNPs was confirmed in 36 isolates from the outbreak in 2009-10 [29]. Most markedly, these two SNPs were also identified in the Norwegian isolates from the year 2000 , in addition to all other tested SNPs characteristic for the more recent outbreak isolates. In summary, all strains isolated between the years 2000 and 2012 which were analysed in our and in previous studies shared the same 22 SNPs including the two highly distinctive "heroinspecific' SNPs.

\section{Pilot study on retrospective}

case finding in Germany

Retrospective case finding was performed by two approaches and is here presented in brief. First, medical personnel from 10 academic medical centres from different parts of Germany responded to a questionnaire to discover retrospectively anamnestic indications for possible clinical signs and symptoms of injection anthrax for the period between January 2009 and spring 2011. For this clinical search the following case definition of injection anthrax was used: 'All cases with history of current heroin use and with clinical picture of massive oedema, compartment syndrome and/or a necrotising fasciitis at the injection site are considered possible injection anthrax.'

Second, a serological investigation was conducted for which 288 serum samples were available. In spring 2011, 44 anonymised sera were obtained in cooperation with the Ministry of Justice of Baden-Wuerttemberg from 20 correctional facilities located in this federal state. Two hundred forty-four capillary blood samples collected as dried blood spots were collected from May until July 2011 in framework the DRUCK-Study, a seroand behavioural survey directed on the risk of viral infections among injecting drug users in Berlin. This study was piloted by the HIV/AIDS, sexually transmitted and blood-borne infections unit, department for Infectious Disease Epidemiology, Robert Koch Institute, Berlin, in close collaboration with low threshold dropin facilities in Berlin. Questions on previous clinical signs and symptoms compatible with drug-related anthrax were added to the questionnaire. Informed consent was provided by all study participants and the study was approved by the Federal Commissioner for Data Protection and Freedom of Information as well as the respective responsible Ethics Review Committee. 
The sera were tested for specific antibodies against the anthrax toxin component protective antigen (PA) using an accredited in-house ELISA (specificity 100\%; sensitivity 1:16,000 for sera, 1:24,000 for plasma) and Western blot analysis (specificity 100\%; sensitivity 1:200,000 for sera, 1:100,000 for plasma). In the case of positive results it was intended to test against further anthrax antigens (LF, EF).

The clinical study identified one male heroin consumer from the north of Germany, with acute soft tissue inflammation, abscess and sepsis by anamnestic investigation, but serology did not confirm anthrax. Questionnaires accompanying the serological study revealed anamnestic clinical signs that could correspond with injection anthrax in 34 of 288 individuals (compartment syndrome $n=24,8.3 \%$; fasciitis $n=10$, $3.5 \%)$. All 288 sera were negative for antibodies against PA in ELISA and also Western blot where tested.

\section{Discussion}

Through molecular analyses we obtained evidence that a similar source of contamination of heroin, causing injection anthrax in IDUs, could have been active at least since the year 2000. The typing approaches showed that the $B$. anthracis isolates from the first injection anthrax patient in Norway in 2000 was almost identical in the studied key elements for molecular typing, with the strain causing an outbreak among IDUs and represented in the study by six isolates obtained from five clinical cases between 2009 and 2012. Earlier SNP analyses of a large strain collection showed the outbreak strain is closest related to strains from a certain region in Turkey, while it is not related to strains from Afghanistan or Pakistan, the countries assumed to be the primary source of the heroin consumed in Europe [4,29]. However, higher numbers of typed strains from these regions might be required to localise where the putative contamination of the heroin occurred.

In our study, the MLVA-profile from seven isolates and one blood sample revealed the presence of four highly related genotypes, differing only in two highly mutable markers, Bams30 and pX02. While the former difference was found in the same sample from a patient in the 2009 outbreak (A112a and b), the plasmid marker differed between the isolates from the cases in 2000, 2009-10 and 2012, respectively. All other markers tested were identical, and therefore the four different MLVA genotypes can be considered as one strain causing the outbreak.

Previous studies confirmed that MLVA markers are stable during routine bacteriological diagnosis and passage in mice and rabbits [30,31], but the analysis of animal outbreaks in Namibia showed that especially the markers Bams3o and $\mathrm{pXO}_{2}$ are frequently mutating. Deviations in only one highly mutable marker, particularly the plasmid marker $\mathrm{pXO} 2$, in temporally distant isolates from a defined endemic region are well known [25]. The putative evolutionary analysis generating minimum spanning trees clusters such isolates into single complexes. Combined with epidemiological data gained in the investigation of outbreak scenarios, such complexes of highly related genotypes can be considered the same outbreak strain.

MLVA data are placing the group of anthrax isolates related to drug abuse in a distinct but closely related cluster on the background of about 900 isolates from Europe, Asia, and southern Africa. Without the possibility to compare the clinical isolates with any isolates from the source of infection it remains speculative whether the differences found are the result of newly arising mutations during the course of infection or whether the drugs injected by the IDUs were already contaminated with different genotypes. In the latter case, these markers could be useful in tracing back the source of contamination to its origin.

In view of the current understanding of the evolutionary development of $B$. anthracis [28], measurable variations in repetitive sequences would be expected to occur only during replication within an infected host. Earlier investigations on $B$. anthracis strains after in vivo passage in artificially infected laboratory animals failed to reveal newly arisen mutations in any marker $[30,31]$. In nature rather slowly proceeding or even chronic courses of disease, occurring in host species with low susceptibility for anthrax may be the cause for the emergence of new genotypes. Whether this is the case also in human hosts can only be unravelled once the source of infection is available for comparison.

The results taken together show that all investigated isolates are closely related and it can be concluded that they belong to the same $B$. anthracis strain despite small observed variations.

For SNP analyses we followed the schemes described by van Ert et al in 2007 and Price et al in 2012 [28,29]. The whole cascade of investigation including two very specific SNPs indicates that the isolate A315 obtained from a heroin user with anthrax in Norway in 2000 was identical in all markers with the here investigated isolates from 2009 to 2012 . Furthermore the results showed that our strains were completely identical with the previously analysed strains from the 2009-10 and 2012 outbreaks [29,32]. These analyses provide further evidence that all isolates from anthrax patients probably infected by contaminated heroin samples belong to one similar outbreak strain.

This may imply that the contamination of heroin is an on-going process and could occur during the processing of heroin samples in facilities exposed to the identified strain of $B$. anthracis. It cannot be excluded that more infections not recognised by clinical examination or laboratory investigation have occurred, especially if the sudden death of an IDU was ascribed to heroin intoxication. The outbreaks identified may represent 
the tip of an iceberg, recognised because high numbers of individuals were affected and the elevated awareness of clinicians as the result of the outbreak in 2009-10. Thus, it is highly important to maintain this awareness by clinicians, microbiological laboratory staff and public health authorities as well as street workers and heroin users themselves. Early detection of new cases will improve the chances of successful treatment of an otherwise often fatal injection anthrax infection and allow the immediate implementation of preventive measures. Besides injection anthrax, further forms of application of heroin causing diverse manifestations of anthrax e.g. respiratory anthrax after inhalation, should be taken into account in this context.

It is possible in general to infer a previous exposure to $B$. anthracis from the detection of anthrax-specific antibodies in sera $[14,33,34]$. Serology could be applied to support diagnoses in late stages of acute anthrax and in retrospective epidemiological investigations to discover patients who had been exposed to $B$. anthracis or have recovered from a clinical disease compatible with anthrax [6]. However, a serological pilot study including 288 heroin consumers performed in two regions of Germany, Berlin and south-west Germany during 2009 to 2011, did not reveal possible additional anthrax cases. The limitations of this study were firstly that samples were only available from two regions in Germany and it can thus not be excluded that positive cases in other regions were missed. Secondly, the number of investigated IDUs was low due to the limited access to individuals in framework of this study. However, to our knowledge, there have been no further publications so far on serological studies focusing on anthrax in IDUs.

In conclusion, high resolution MLVA31 and $\mathrm{SNP}_{13}$ plus a cascade of SNP analyses and two very specific SNPS identified all studied isolates from the anthrax outbreak in IDUs in 2009-10 and 2012 as the same strain. Most interestingly, the Norwegian isolate from the year 2000 was also identified by all applied methods as the same outbreak strain. It can be concluded that most likely the outbreak has been going on since at least the year 2000 with a highly probable similar source of contamination which might be still active. It seems probable that cases have remained undetected since this time and a joint international epidemiological investigation could contribute to clarify this issue. Identification and abolishment of the contamination source would be the most effective preventive measure. However, this is a challenge that could be only achieved by close cooperation of scientists, public health authorities and law enforcement agencies. Awareness by physicians and patients is most important for an early and effective treatment.
Acknowledgements

We would like to thank all participants in the serological study for providing the samples. Expert technical assistance by Tatjana Franz is highly appreciated. We also thank Anna Rohleder for editorial support in preparation of the manuscript and Ursula Erikli for copy-editing. The work was partially supported by the EU Joint Action QUANDHIP, EAHC contract number 201021 02/ A-100 905.

\section{References}

1. Hugh-Jones M, Blackburn J. The ecology of Bacillus anthracis. Mol Aspects Med. 2009;30(6):356-67. http://dx.doi. org/10.1016/j.mam.2009.08.003. PMid:19720074.

2. World Organisation for Animal Health (OIE), World Health Organization (WHO), Food and Agriculture Organization of the United Nations (FAOAnthrax in humans and animals. Fourth edition.Geneva: WHO; 2008.

3. Hicks CW, Sweeney DA, Cui X, Li Y, Eichacker PQ. An overview of anthrax infection including the recently identified form of disease in injection drug users. Intensive Care Med. 2012;38(7):1092-104. http://dx.doi.org/10.1007/s00134-0122541-0. PMid:22527064. PMCid:3523299.

4. Health Protection Scotland (HPS), National Services Scotland (NHS). An Outbreak of Anthrax Among Drug Users in Scotland, December 2009 to December 2010. A report on behalf of the National Anthrax Outbreak Control Team. Glasgow: HPS. Available from: http://www.documents.hps.scot.nhs.uk/giz/ anthrax-outbreak/anthrax-outbreak-report-2011-12.pdf

5. Jallali N, Hettiaratchy S, Gordon AC, Jain A. The surgical management of injectional anthrax. J Plast Reconstr Aesthet Surg. 2011;64(2):276-7. http://dx.doi.org/10.1016/j. bjps.2010.06.003. PMid:20615773.

6. Grunow R, Verbeek L, Jacob D, Holzmann T, Birkenfeld G, Wiens D, et al. Injection Anthrax-a New Outbreak in Heroin Users. Dtsch Arztebl Int. 2012;109(49):843-8. PMid:23267409. PMCid:3528063.

7. Knox D, Murray G, Millar M, Hamilton D, Connor M, Ferdinand $\mathrm{RD}$, et al. Subcutaneous anthrax in three intravenous drug users: a new clinical diagnosis. J Bone Joint Surg Br. 2011;93(3):414-7. http://dx.doi.org/10.1302/0301620X.93B3.25976. PMid:21357967.

8. Sweeney DA, Hicks CW, Cui X, Li Y, Eichacker PQ. Anthrax infection. Am J Respir Crit Care Med. 2011;184(12):133341. http://dx.doi.org/10.1164/rccm.201102-0209Cl. PMid:21852539. PMCid:3361358

9. Booth MG, Hood J, Brooks TJ, Hart A. Anthrax infection in drug users. Lancet. 2010;375(9723):1345-6. http://dx.doi. org/10.1016/S0140-6736(10)60573-9

10. European Centre for Disease Prevention and Control (ECDC). Epidemiological update: anthrax cases among people who inject drugs. Stockholm: ECDC. 8 Mar 2013. Available from: http://ecdc.europa.eu/en/press/news/Lists/News/ ECDC_DispForm.aspx?List=32e 43ee8-e230-4424-a78385742124029 a \& ID $=860$ \& RootFolder $=\% 2$ Fen $\% 2$ Fpress $\% 2$ Fnew S\%2FLists \%2FNews

11. German Committee on Biological Agents (ABAS). Technical Rules for Biological Agents 466 - Classification of Prokaryotes (Bacteria and Archaea) into Risk Groups. http://www.baua. de/en/Topics-from-A-to-Z/Biological-Agents/TRBA/pdf/TRBA466.pdf;jsessionid=935E7A8B0476DCAF3E99BB41705691 4C.1_cid380? blob=publicationFile \& $v=3$

12. Spotts Whitney EA, Beatty ME, Taylor TH, Jr., Weyant R, Sobel J, Arduino MJ, et al. Inactivation of Bacillus anthracis spores. Emerg Infect Dis. 2003;9(6):623-7. http://dx.doi.org/10.3201/ eido906.020377. PMCid:3000133.

13. Grunow R, Porsch-Ozcurumez M, Splettstoesser W, Buckendahl A, Hahn U, Beyer W, et al. Monitoring of ELISA-reactive antibodies against anthrax protective antigen (PA), lethal factor (LF), and toxin-neutralising antibodies in serum of individuals vaccinated against anthrax with the PA-based UK anthrax vaccine. Vaccine. 2007;25(18):3679-83. http://dx.doi. org/10.1016/j.vaccine.2007.01.056. PMid:17287051.

14. Quinn CP, Dull PM, Semenova V, Li H, Crotty S, Taylor TH, et al. Immune responses to Bacillus anthracis protective antigen in patients with bioterrorism-related cutaneous or inhalation anthrax. J Infect Dis. 2004;190(7):1228-36. http://dx.doi. org/10.1086/423937. PMid:15346332.

15. Walsh J, Pesik N, Quinn CP, Urdaneta V, Dykewicz CA, Boyer $A E$, et al. A case of naturally acquired inhalation anthrax: clinical care and analyses of anti-protective antigen immunoglobulin $\mathrm{G}$ and lethal factor. Clin Infect 
Dis. 2007;44(7):968-71. http://dx.doi.org/10.1086/512372. PMid:17342650.

16. Ringertz SH, Hoiby EA, Jensenius M, Maehlen J, Caugant DA, Myklebust A, et al. Injectional anthrax in a heroin skin-popper. Lancet. 2000;356(9241):1574-5. http://dx.doi.org/10.1016/ S0140-6736(00)03133-0.

17. Radun D, Bernard H, Altmann M, Schöneberg I, Bochat V, van Treeck U, et al. Preliminary case report of fatal anthrax in an injecting drug user in North-Rhine-Westphalia, Germany, December 2009. Euro Surveill. 2010;15(2): pii=19464. Available from: http://www.eurosurveillance.org/ViewArticle. aspx?Articleld=19464. PMid: 20085693.

18. Robert Koch-Institut R Ein dritter Fall von Anthrax bei einem i. v. Heroinkonsumenten in Deutschland [Third anthrax case in an injecting heroin user in Germany]. Epidemiologisches Bulletin. 2010;1(49):492-93. Available from: https://www.rki. $\mathrm{de} / \mathrm{DE} /$ Content/Infekt/EpidBull/Archiv/2010/Ausgaben/49_10. pdf?_blob=publicationFile

19. ProMED-mail. Anthrax - Germany (08): (Berlin) ongoing investigations. Archive Number 20120713.1200646. $13 \mathrm{Jul}$ 2012. Available from: http://www.promedmail.org/direct. php?id=1200646

20. ProMED-mail. Anthrax, human - Denmark (03): fatal conf. heroin case. Archive Number 20120709.1195198. o9 Jul 2012. Available from: http://www.promedmail.org/direct. php?id=20120709.1195198

21. ProMED-mail. Anthrax - France: (RA) conf. heroin case. Archive Number 20120714.1201908. 14 Jul 2012. Available from: http:// www.promedmail.org/direct.php?id=20120714.1201908

22. ProMED-mail. Anthrax, human - UK (02): (Scotland) new heroin related case, alert. Archive Number 20120725.1214623. 25 Jul 2012. Available from: http://www.promedmail.org/direct. php?id=20120725.1214623

23. ProMED-mail. Anthrax, human - Denmark (04): 2nd heroin associated case. Archive Number 20120727.1217584. 27 Jul 2012. Available from: http://www.promedmail.org/direct. php?id=20120727.1217584

24. ProMED-mail. Anthrax, human - UK (06): (Wales) new heroin case. Archive Number 20120907.1285521. 07 Sep 2012. Available from: http://www.promedmail.org/direct. php?id=20120907.1285521

25. Beyer W, Bellan S, Eberle G, Ganz HH, Getz WM, Haumacher R, et al. Distribution and Molecular Evolution of Bacillus anthracis Genotypes in Namibia. PLoS Negl Trop Dis. 2012;6(3):e1534.

26. Keim P, Price LB, Klevytska AM, Smith KL, Schupp JM, Okinaka R, et al. Multiple-locus variable-number tandem repeat analysis reveals genetic relationships within Bacillus anthracis. J Bacteriol. 2000;182(10):2928-36. http://dx.doi. org/10.1128/JB.182.10.2928-2936.2000. PMid:10781564. PMCid:102004.

27. Lista F, Faggioni G, Valjevac S, Ciammaruconi A, Vaissaire J, le Doujet C, et al. Genotyping of Bacillus anthracis strains based on automated capillary 25 -loci multiple locus variablenumber tandem repeats analysis. BMC Microbiol. 2006;6:33. http://dx.doi.org/10.1186/1471-2180-6-33. PMid:16600037. PMCid:1479350.

28. Van Ert MN, Easterday WR, Huynh LY, Okinaka RT, HughJones ME, Ravel J, et al. Global genetic population structure of Bacillus anthracis. PLoS One. 2007;2(5):e461. http:// dx.doi.org/10.1371/journal.pone.0000461. PMid:17520020. PMCid:1866244.

29. Price EP, Seymour ML, Sarovich DS, Latham J, Wolken SR, Mason J, et al. Molecular Epidemiologic Investigation of an Anthrax Outbreak among Heroin Users, Europe. Emerg Infect Dis. 2012;18(8):1307-13. http://dx.doi.org/10.3201/ eid1808.111343. PMid:22840345. PMCid:3414016.

30. Beyer W, Turnbull P. Anthrax in animals. Mol Aspects Med. 2009;30(6):481-9. http://dx.doi.org/10.1016/j. mam.2009.08.004. PMid:19723532.

31. Beyer W, J. Lazak, K. Hilss, R. Böhm Stability tests of 31 VNTR markers in routine diagnostics (Poster at Bacillus anthracis, $B$. cereus and $B$. thuringiensis International Conference). Bacillus anthracis, $B$ cereus and B thuringiensis International Conference, August 30 - September 3, Santa Fe, USA, Abstract book, p 45. 2009.

32. Holzmann T, Frangoulidis D, Simon M, Noll P, Schmoldt $S$, Hanczaruk $M$, et al. Fatal anthrax infection in a heroin user from southern Germany, June 2012. Euro Surveill. 2012;17(26): pii=20204. Available from: http://www. eurosurveillance.org/ViewArticle.aspx?Articleld $=20204$. PMid:22790532.

33. Kissling E, Wattiau P, China B, Poncin M, Fretin D, Pirenne Y, et al. B. anthracis in a wool-processing factory: seroprevalence and occupational risk. Epidemiol Infect. 2012;140(5):87986. http://dx.doi.org/10.1017/S0950268811001488. PMid:21835070.
34. Wattiau P, Govaerts M, Frangoulidis D, Fretin D, Kissling E, Van Hessche $M$, et al. Immunologic response of unvaccinated workers exposed to anthrax, Belgium. Emerg Infect Dis. 2009;15(10):1637-40. http://dx.doi.org/10.3201/eid1510.081717. PMid:19861061. PMCid:2866386.tincidunt. Suspendisse neque arcu, malesuada dignissim condimentum et, gravida et lectus. 